\title{
Disclosure of Sustainable Development Goals (SDGs) in Bangladesh: A Study on DSE Listed Companies
}

\author{
Trina Saha*, Fatema Jannat \\ Assistant Professor, Department of Business Administration (DBA), Noakhali Science and Technology University, BANGLADESH \\ *trina.bba@nstu.edu.bd
}

https://doi.org/10.18034/abr.v11i3.594

\begin{abstract}
Business organizations can secure their future growth by implementing sustainable development goals into their business process. With the advancement in accounting, the nature of reporting practices is also changing. Now reporting is not merely restricted to financial statements, information related to social contribution, environment; sustainability has attained much interest in the corporate world. This study aims to find out the nature and extent of reporting practices of SDGs by some listed companies of the Dhaka Stock Exchange. The samples of this study are 40 companies from several sectors, including banks, pharmaceuticals, insurance, ceramics, telecommunication, etc. are selected based on market volume. Content analysis based on 16 recommendations under governance, strategy, management approach, and performance and targets found from an extensive literature review has been made to fulfill the research objectives. Annual reports from 2019 to 2020 are examined to determine the disclosure issues based on given recommendations. The findings reveal the minimum level of direct disclosure of SDGs but a satisfactory level (around 87.5\%) of exposure about the consciousness of SDGs and involvement of SDG in strategy (approximately $63.75 \%$ ). This study is pioneering because there is very little research about it in our country; thus, it is expected to encourage more research on this subject.
\end{abstract}

JEL Classifications: G10, G38, I38

Key words: Sustainable Development Goals, Reporting Guidelines, Disclosure, Dhaka Stock Exchange (DSE)

\section{INTRODUCTION}

Sustainability means creating long-term significance considering the environment and the elements in which an organization runs its activities. And development is a multidimensional process that involves economic growth, equality, environmental safety, eradication of poverty, etc. To sustain itself in the competitive business world, the organization must include sustainability goals in its business strategy. They can play a significant role in the path of sustainable development. After witnessing remarkable progress towards the achievement of Millennium Development Goals (MDGs), which were adopted by 189 members of United Nations, in 2015, all member countries of United Nations adopted seventeen Sustainable Development Goals, with 169 other goals, which are also known as Global Goals, committing themselves to make sustainable progress in ending poverty, protecting the planet and ensuring peace and prosperity for all by 2030.
MDGs and SDGs share the same target at their core, but the SDGs focus on the holistic approach to development that MDGs failed to focus on. SDGs involve key stakeholders in the society, planet, and prosperity, which also match the triple bottom line reporting by environment-friendly business organizations. SDGs also beat MDGs to ensure quality and timely acquisition of the goals.

Bangladesh has already met the targets of MDGs; it has made remarkable progress in poverty reduction, decreasing mortality rate, increasing the number of students in primary schools, etc. Now it is on the way to achieving SDGs; it has integrated SDGs into its five-year national plan, including all sectors of local governments, including organizations from both the public and private sector. Business organizations play a vital role in the economic development of any country, and Bangladesh is no exception to this. Corporate reports are the most significant communication channel that a business 
organization has with all its stakeholders. Recently there has been a change in the reporting practice of corporations; they are including sustainable factors in their reports. Although this practice is not satisfactory to date in Bangladesh, the number of practicing organizations is increasing day by day. In general, companies publish this type of information in their annual reports, websites, social responsibility reports, etc. At present, there are 590 listed companies on Dhaka Stock Exchange. This study targets to find out the reporting practice of SDGs by those companies, and the findings from this study will help the regulatory authorities of the Bangladesh Government to take necessary measures in the way of achieving SDGs.

The main objective of this study is to find out the present scenario of sustainable development goals reporting in Bangladesh. It also aims to find out the answers to the following research questions:

- Do the listed companies of DSE disclose SDGs in their reports?

- How and to what extent are they disclosing SDGs?

- What are the reasons for not disclosing SDGs?

\section{JUSTIFICATION OF THE STUDY}

SDGs are not only an aspiring framework for nations, for governments but also a roadmap for business organizations to have a long-term positive impact on customers' minds and also on the environment. Though SDGs are universal goals, they must be addressed at every single level of the national arena. No matter what is the size of the organization, what are their products or activities, regardless of these, they can contribute to the achievement of SDGs through their performance and reporting. There has been some remarkable research work on sustainability reporting, environmental reporting, Corporate Social Responsibility reporting by companies in Bangladesh, but till now, no research on SDGs reporting. So there is a research gap, and the findings of this research can be used for decision-making related to SDGs and for further research on this field. These issues encouraged the current research to be pursued.

\section{REVIEW OF RELATED LITERATURE}

\section{Sustainable Development}

Basiago (1999) defined sustainability as a means of maintaining some entity, consequence, or procedure over a long period. Reyes (2001) defined development as a condition of society where the needs of its population, such as education, housing, nutrition, and health service, are met by using natural resources and systems rationally and in a sustainable way, and their cultures are valued within the community structure.
Mensah (2019) found that sustainable development has gained much responsiveness in the academic, governance, development, and involvement space, and many entities, including governmental and non-governmental, have included it as a development paradigm. The author also suggested that sustainable development can be achieved through joint efforts at various stages, including social, environmental, and economic aspects. It can be implanted through complex interactions among the goals and targets.

In Brundtland's (1987) report, sustainable development was pictured as a straightforward process rather than a fixed state of harmony. It is the change of resources, investment, and technological development inconsistent with the present as well as the future. With the rapid growth of the population, there is increasing pressure on resources; for this reason, the size and growth of the population should be kept in harmony with the changing ecosystem to pursue sustainable development. Singh (2016), found the word sustainability as a fashionable concept that is very expensive to implement by a large number of corporations, firms, and governments.

\section{Sustainable Development Goals}

Adams (2020) defined sustainable development goals as an instrument of maximizing value-creating that enhances knowledge about the impact of business activities on sustainable development.

Pedersen (2018) found that despite the successful implementation of MDGs, there is still major material global challenges related to industrial production, consumption, and urbanization, which need to be solved by taking global action to a much wider scope. He identified MDGs as political agenda for the developing world, primarily focusing on poverty, education and diseases and sustainable development as an agenda for the developed world, especially for the private sector, as a great gift for business with a much clearer set of long term goals as well as a stronger alliance among policymakers.

Neves (2018) suggested a sustainable development goal as a three vector approach comprising of society, environment, and economy. These vectors are interdependent from each other, implying a more complex development model and a balanced approach that will be positive for people, the planet, and prosperity. He also identified several groups of critics related to terms, definitions, contradictions, inconsistencies; some critics think SDGs are people and planet-oriented, some discuss the strategy the feasibility of achieving these goals.

Kroll et al. (2019) put importance on the minimization of trade-offs across the SDGs. They examined the nature of different countries dealing with interlinkages for SDG achievement by 2030. They classified these interactions into two groups comprising of synergies and trade-offs. They found interactions within SDGs which is a positive 
sign of the successful implementation of SDGs within 2030. They also offered a starting point for researchers and policymakers to solve the challenge of interactions between SDGs.

Breuer et al. (2019) believed that successful implementation of all SDGs would depend upon untying the complex interactions between goals and targets. They suggested ideas of translating SDG interdependencies into policy action. They provided an overview of existing frameworks for the conceptualization, Interdependencies, and interlinkages between SDGs, advantages, and limitations of these frameworks focusing on weaknesses, applicability, and utility of policy strategies development for comprehensive planning and implantation of SDGs.

\section{Corporate Sustainability and SDGs Reporting}

Christofi et al. (2012) focused on how sustainability safeguards the well-being of the human population and protects the environment from pollution and resource degradation resulting from unregulated manufacturing actions. They used sample firms from the DJSI world index and GRI-G3 guidelines membership list, and they suggested that tipple bottom line reporting needs further standardization so that it can avoid and give early warning about any corporate mismanagement which can cause detrimental socio-economic consequences to general investors and consumers. They also suggested that Security Exchange Commission and Financial Accounting Standard Board should come forward by taking strong steps for standardization and enforcement of corporate socio-environmental disclosures.

Topple et al. (2017) examined 112 multinational enterprises of Southeast Asian nations to evaluate sustainable business practices. They found that there is a strong influence of the commitments such as the use of materiality analysis to identify and prioritize sustainability issues, corporate strategies, etc., from headquarters of MNEs on their sustainability practices. They suggested that incorporation of SDGs within MNEs can be achieved through the practice of international sustainability standards since these standards are wellacknowledged and, by this time, are embraced by MNEs.

Agarwal et al. (2017) proposed a three-phased approach to business engagement in the SDGs comprising prioritizing an understanding of impact, aligning core business strategies with the SDGs, and working towards systematic change. They argued that the health and prosperity of business and society are interdependent on each other, thus if businesses want to contribute truly to the achievement of the SDGs, they should rethink their role in society, they should avoid narrow, short term and profit-focused approaches and take a holistic approach by basing their engagement, aligning their core business strategies with SDGs and working with others to make a systematic change and a more human-oriented economy.
PWC (2015), tried to find out the engagement of business with the SDGs, understanding their vision and plans. They found a good awareness of SDGs resulting in great engagement as $71 \%$ of businesses are planning their engagement with SDGs, 13\% already have identified the tools they need to assess the impact against SDGs, and $90 \%$ of citizens think that businesses should engage themselves with SDGs and also little consistency in approach.

\section{Accounting and Reporting of SDGs}

CGMA (2018) reported that management accountants could play a critical role by aligning business strategies with sustainable activities, providing timely information to the decision-makers about sustainability factors for the implementation of these factors into business planning and reporting so that they can contribute to the successful implementation and advancement of SDGs as well as monitoring and evaluating their impact.

Makarenko \& Plastun (2017) discussed the role of accounting in the achievement of SDGs as they are highly involved in this process and provided a holistic vision of the role in SDGs 4, 5, 8,12,13,17, and 17 by using corporate sustainable development gradation comprising of strategic, operational and reporting. They found a correlation between a professional accountant's role and gradations of sustainable corporate development. They described accountants' role as creators of values at the strategic level, providers of sustainable development values at the operating level and keepers, and reporters at the reporting level.

CPA (2020) identified significant roles of professional accountants in governance, risk management and control, and decision making. For their important role-playing in attaining SDGs, workshops and meetings are being conducted by the International Federation of Accountants, Professional Accountants in Business Committee outlining the key opportunities for global accountants so that they can easily contribute to the attainment of SDGs. To support the disclosures of SDGs, a report has been published by the Association of Chartered Certified Accountants (ACCA), Institute of Chartered Accountants of Scotland (ICAS), Chartered Accountants Australia and New Zealand (CA ANZ), the International Integrated Reporting Council (IIRC) and the World Benchmarking Alliance. The Recommendations are authored by Carol Adams, Professor of Accounting, with Paul Druckman and Russell Picot, Honorary Professors at Durham University Business School (IFAC, 2020).

They mentioned several forms of SDG disclosures such as an annual report, annual integrated reports, strategic reports, etc. They also suggested that SDGs should be disclosed following the reference of fundamental concepts and principles related to SDG disclosure. Their recommendations support material sustainable 
development risk and opportunities, the process of the organization's contribution and engagement in the achievement of SDGs, and how they communicate the implications and impact on the achievement of SDGs.

\section{SDGs and Bangladesh}

Citizen's Platform for SDGs (2019), reported Bangladesh as one of the front runners in institutionalizing SDG implementation mechanism. Bangladesh has taken several measures, including the establishment of a highlevel platform, coordinating activities of intergovernmental agencies, integration of SDGs into policies, etc. It has taken a whole society approach by involving nonstakeholders in the SDG implementation process. Private sectors of Bangladesh are engaging themselves in this process by safeguarding job circumstances, creating consciousness to diminish pollution, forming different foundations and funds to enhance their CSR activities, etc.

Rahman (2020) stated that Bangladesh has already coincided with SDGs into the seventh five-year plan, providing a good chance to integrate SDGs into the national plan. Among 17 goals, 14 goals are fully aligned, and three goals are partially aligned with this plan. As a result of several initiatives taken by the Government of Bangladesh, it is seen that Bangladesh has gained significant progress in achieving SDG 4 as well as other goals. With the government agencies, non-government organizations are also playing a crucial role at the root level by creating awareness among people about the hostile effect of climate change, health, nutrition, education, water, sanitation, agriculture, food, gender equality, etc. The private sector is also taking several initiatives such as investment in strengthening infrastructure, Economic and market research, a Training program for developing women entrepreneurship, Workplace Safety, Environmental sustainability, Promotion and protection of trade, commerce, and manufactures of Bangladesh, Bridging the communication gap digitally, Ensuring energy security for Bangladesh, etc. All of these activities are related to the achievement of SDGs. It is also stated in this study that Bangladesh is in the second phase of SDG implementation. It is facing several challenges such as lack of up-to-date data, ambiguities created by data variances, addressing gaps, etc. Thus addressing these challenges is a major task from now to 2030 , and success in this way can be achieved by involving all concerned stakeholders.

\section{MetHodology}

This section explains the methodological approach used by this study.

\section{Sample size}

Currently, there are a total of 22 industrial sectors in the Dhaka Stock Exchange (DSE) which accommodate 578 listed companies (as of 20 July 2020). Our sample size is the top 40 companies included in DSE based on market volume, which represents the number of shares traded in a stock. This sample size represents around $10 \%$ of the total companies listed on the basis of market volume.

\section{Sources of Data and Data collection}

The study is based on information from secondary data sources. SDGs can be disclosed in several documents. Secondary data from the financial reports, non-financial reports, management reports, sustainability reports, integrated reports, environmental disclosure reports, corporate social responsibility reports, and websites of the sample companies for the financial year 2019-2020 have been used to complete this work.

\section{Data Analysis technique}

The content analysis method has been used in this research. The analysis is done based on the SDG disclosures recommendations provided by Carol Adams, Paul Druckman, and Russell Picot in their report of Sustainable Development Goals Disclosure (SDGD) Recommendations. The disclosures themes are Governance, Strategy, Management Approach, and Performance and targets. Words, statements, phrases, themes related to the above 16 recommendations have been analyzed using statistical techniques. For each element, a score of 1 is assigned if the item is disclosed and 0 otherwise. Based on the score earned by companies and the collected documents, the percentage of our sample companies disclosing SDGs, the location of their disclosure, and also the reasons for not disclosing SDGs can be found.

\section{ANALYSIS AND FINDINGS}

Our main objective is to find out SDGs disclosure practices by Bangladeshi companies. The following table shows the number of companies addressing SDGs. Here our concentration is on the 16 recommendations under Governance, Strategy, Management Approach, and Performance Targets. We found that none of these companies directly disclose SDGs in their annual reports, websites, or other integrated reports; still, maximum companies are disclosing their concern regarding sustainability which we can relate with the abovementioned recommendations. We have included themes, words, and sentences to determine whether or not they are addressing SDGs in their organizational culture, policy-making, and strategy development. We see that 36 companies out of 40 sample companies are disclosing their concern about SDGs; among these, we have counted the maximum number of insurance companies, i.e., 12 , out of these 11 companies are concerned about SDGs. In our next largest sector in the banking industry, we have taken 10 private commercial banks as samples, and all of these banks are aware of SDGs disclosure. 
Table 1: Overall Disclosure

\begin{tabular}{|l|c|c|c|}
\hline Industry & $\begin{array}{c}\text { Number of } \\
\text { Companies }\end{array}$ & $\begin{array}{c}\text { Companies } \\
\text { addressing } \\
\text { SDGs } \\
\text { disclosure }\end{array}$ & $\begin{array}{c}\text { Companies } \\
\text { addressing } \\
\text { SDGs } \\
\text { disclosure } \\
(\%)\end{array}$ \\
\hline Pharmaceuticals & 4 & 4 & 100 \\
\hline Banks & 10 & 10 & 100 \\
\hline Ceramics & 2 & 2 & 100 \\
\hline Insurance & 12 & 11 & 91.6 \\
\hline Telecommunication & 2 & 2 & 100 \\
\hline Steel & 2 & 1 & 50 \\
\hline Others & 8 & 5 & 62.5 \\
\hline Total & 40 & 35 & \\
\hline Source: Annual Reports & \\
\hline
\end{tabular}

\section{Disclosure on Governance}

The following table 2 shows disclosure practices under the theme of governance. We see maximum organizations from our sample are addressing sustainability in their governance process. Here we focused on disclosure about material sustainable development issues, risks, and opportunities associated with these issues, stakeholders' involvement, and organizations' cultural appropriateness regarding the achievement of goals. But less than an average number of organizations are not disclosing any direct statement from board chair in their annual reports or websites, and none of these organizations are disclosing any time range for implementing disclosure recommendations, and very few are disclosing their competencies regarding sustainability issues.

Table 2: Disclosure Index (DI) of Governance

\begin{tabular}{|c|c|c|}
\hline \multicolumn{2}{|r|}{ Recommendations regarding Governance } & DI (\%) \\
\hline G1 & 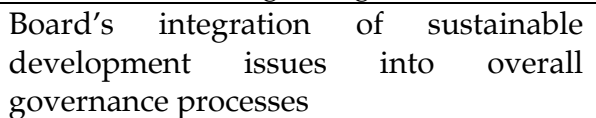 & 80 \\
\hline $\mathrm{G} 2$ & $\begin{array}{l}\text { Include a statement from the Board Chair } \\
\text { accepting responsibility for the SDG } \\
\text { Disclosures }\end{array}$ & 45 \\
\hline G3 & $\begin{array}{l}\text { Disclose the time period of implementing } \\
\text { SDGD Recommendations and where any } \\
\text { SDGD Recommendation is not, or will } \\
\text { not, be disclosed; explain why not }\end{array}$ & 0 \\
\hline G4 & $\begin{array}{l}\text { Describe the Board's competencies } \\
\text { concerning sustainable } \\
\text { issues and the mechanisms }\end{array}$ & 13 \\
\hline
\end{tabular}

\section{Disclosure on Strategy}

Under this theme, there are two recommendations. Under the first recommendation, there are three sub recommendations. Based on those, we have found that around $72.5 \%$ of sample companies described sustainable development issues, including the risk and opportunities of their strategy and value created for the stakeholders through their sustainable steps. And around 67.5\% are disclosing their investment in human resources, infrastructure, education, health sector, etc., along with their regular investment. Some companies disclosed quantitative information; some disclosed qualitative information, and some disclosed both.

Table 3: Disclosure Index of Strategy

\begin{tabular}{|l|l|c|}
\hline \multicolumn{2}{|l|}{ Recommendations regarding Strategy } & DI (\%) \\
\hline S1 & $\begin{array}{l}\text { Describe how consideration of } \\
\text { sustainable development issues has } \\
\text { influenced strategy and its impact } \\
\text { on the achievement of the SDGs }\end{array}$ & 72.5 \\
\hline S2 & $\begin{array}{l}\text { Disclose investments in and benefits } \\
\text { generated from opportunities } \\
\text { arising from sustainable } \\
\text { development issues }\end{array}$ & 67.5 \\
\hline \multicolumn{2}{|l|}{ Source: Annual Reports } & \\
\hline
\end{tabular}

\section{Disclosure on Management Approach}

Under this theme, we have considered two recommendations, including eight sub recommendations. We see that around $72.5 \%$ of companies determined relevant, sustainable issues and their positive and negative impact on the organization process. They are also changing the business model to enjoy the advantages of sustainability issues in achieving long-term goals. But under the second recommendation, we didn't find any company making a scenario analysis regarding SDG implementation.

Table 4: Disclosure Index of Management Approach

\begin{tabular}{|l|l|c|}
\hline \multicolumn{2}{|l|}{$\begin{array}{l}\text { Recommendations regarding Management } \\
\text { Approach }\end{array}$} & $\begin{array}{c}\text { DI } \\
(\%)\end{array}$ \\
\hline MA1 & $\begin{array}{l}\text { Disclose how it has integrated } \\
\text { consideration of sustainable } \\
\text { development issues and the SDGs into } \\
\text { the organization's processes }\end{array}$ & 72.5 \\
\hline MA2 & $\begin{array}{l}\text { Describe how a scenario analysis has } \\
\text { been undertaken for the SDGs } \\
\text { identified through the application of the } \\
\text { Fundamental Concepts. }\end{array}$ & 0 \\
\hline Source: Annual Reports \\
\hline
\end{tabular}

\section{Disclosure on Performance and targets}

In this theme, there are eight recommendations. From the following table, we see that no company is disclosing any information about the performance report of SMART targets and the impact of their lobbying activities and taxation practices on SDG. Very few disclosed financial and non-financial impacts on the achievement of goals. Maximum companies (around 70\%) integrated sustainability into their mission and vision; the impact of this also can be seen in their financial reports as well as financial forecasting. Around $40 \%$ of companies disclosed information about their approach to managing risk, opportunities related to SDG, and the impact of these activities on value creation. 
Table 5: Disclosure Index of Performance and targets

\begin{tabular}{|c|c|c|}
\hline \multicolumn{2}{|c|}{$\begin{array}{c}\text { Recommendations regarding performance and } \\
\text { targets }\end{array}$} & DI (\%) \\
\hline PT1 & $\begin{array}{l}\text { Describe the connection between the } \\
\text { organization's approach to sustainable } \\
\text { development and its vision and } \\
\text { mission. }\end{array}$ & 70 \\
\hline PT2 & $\begin{array}{l}\text { Describe the organization's approach to } \\
\text { setting targets, including how it is } \\
\text { influenced by the organization's } \\
\text { consideration of the risks, } \\
\text { opportunities, and scenarios related to } \\
\text { sustainable development and the SDGs. }\end{array}$ & 42.5 \\
\hline PT3 & $\begin{array}{l}\text { Disclose the organization's material } \\
\text { positive and negative financial and } \\
\text { non-financial impacts on the } \\
\text { achievement of the SDGs. }\end{array}$ & 22.5 \\
\hline PT4 & $\begin{array}{l}\text { Report performance against the short, } \\
\text { medium, and long-term SMART } \\
\text { targets. }\end{array}$ & 0 \\
\hline PT5 & $\begin{array}{l}\text { Describe how the organization's } \\
\text { approach to sustainable development } \\
\text { has contributed to value creation (or } \\
\text { destruction) for the organization and its } \\
\text { stakeholders. }\end{array}$ & 40 \\
\hline PT6 & $\begin{array}{l}\text { Disclose any material (positive and } \\
\text { negative) impact of the organization's } \\
\text { lobbying activities and taxation } \\
\text { practices on the achievement of the } \\
\text { SDGs. }\end{array}$ & 0 \\
\hline PT7 & $\begin{array}{l}\text { Disclose assumptions concerning } \\
\text { material sustainable development risks } \\
\text { and opportunities in future cash flows, } \\
\text { asset valuations, useful lives, } \\
\text { contingent liabilities. }\end{array}$ & 57.5 \\
\hline PT8 & $\begin{array}{l}\text { Disclose where additional detailed } \\
\text { information on the organization's } \\
\text { impacts can be found. }\end{array}$ & 30 \\
\hline
\end{tabular}

We have found that maximum companies are interested in disclosing information about human rights, social responsibilities, donations provided to educational institutions and infrastructural development, etc. Although most of the companies are aware of sustainability, direct disclosure related to SDG is very minimum.

\section{Location of disclosure related to SDGs}

The following table represents the locations of the annual reports presenting disclosure issues related to sustainability. There was no separate report for sustainable issues. They are disclosing this information in several sections of the annual report. Maximum companies basically disclosed social activities related to SDG 4, SDG 5, SDG 8, SDG 9, SDG 10, and 11 in the human resource report and corporate social responsibility report. More than $40 \%$ of the companies disclosed their awareness about sustainability issues in the chairman's report and director's report. Very few directly disclosed sustainability issues in the mission and vision statement. Disclosure Issues related to SDG 13 were presented in a separate environmental report.

Table 6: Location of disclosure related to SDGs

\begin{tabular}{|l|c|c|c|}
\hline Location & $\begin{array}{c}\text { No. of } \\
\text { Companies }\end{array}$ & Percentage & Rank \\
\hline Directors Report & 14 & $40 \%$ & 6 \\
\hline Chairman's Report & 17 & $48 \%$ & 4 \\
\hline Segment Report & 7 & $20 \%$ & 7 \\
\hline $\begin{array}{l}\text { Human Resource } \\
\text { Report }\end{array}$ & 24 & $68 \%$ & 2 \\
\hline $\begin{array}{l}\text { Risk Management } \\
\text { Report }\end{array}$ & 19 & $54 \%$ & 3 \\
\hline Sustainability Report & 5 & 14 & 8 \\
\hline $\begin{array}{l}\text { Environmental } \\
\text { Report }\end{array}$ & 16 & $45 \%$ & 5 \\
\hline $\begin{array}{l}\text { Vision and Mission } \\
\text { Statement }\end{array}$ & 4 & $11 \%$ & 9 \\
\hline $\begin{array}{l}\text { Corporate Social } \\
\text { Responsibility } \\
\text { Report }\end{array}$ & 31 & $91 \%$ & 1 \\
\hline Source: Annual Reports & & \\
\hline
\end{tabular}

\section{Disclosure level on the basis of the number of} recommendations

Table 7 represents the percentage of companies based on the number of recommendations where it can be seen that only $7.5 \%$ of sample companies are disclosing the maximum number of issues related to recommendations, including G1, S1, S2, MA1, PT1, and PT7. Half of the sample companies disclosed recommendations, including G2, G4, PT2, PT5, and PT8, and 5 companies are not disclosing any information related to sustainability or SDG. Among the sample companies, banks and pharmaceuticals companies are disclosing maximum information related to recommendations taken as the base of this research. The strict regulations provided by authorities can be the reason behind this scenery.

Table 7: Disclosure level on the basis of the number of recommendations

\begin{tabular}{|l|c|c|}
\hline \multicolumn{1}{|c|}{$\begin{array}{c}\text { Number of } \\
\text { recommendations }\end{array}$} & $\begin{array}{c}\text { No. of } \\
\text { Companies }\end{array}$ & Percentage \\
\hline 0 to 5 recommendations & 17 & 42.5 \\
\hline 6 to 10 recommendations & 20 & 50 \\
\hline $\begin{array}{l}11 \text { to } 16 \\
\text { recommendations }\end{array}$ & 3 & 7.5 \\
\hline
\end{tabular}

\section{Disclosure on the basis of overall themes}

From the following table, it is seen that, on average maximum disclosure has been practiced under the theme strategy that is companies are incorporating sustainable goals into their business strategy. Around 39.38\% of the companies are disclosing Board as well as corporate involvement in SDGs through the governance process. 
Performance and targets involved specific issues, and minimum disclosure has been found under this theme.

Table 8: Disclosure on the basis of overall themes

\begin{tabular}{|l|c|}
\hline Themes & Percentage \\
\hline Governance & $39.38 \%$ \\
\hline Strategy & $63.75 \%$ \\
\hline Management Approach & $36.25 \%$ \\
\hline Performance Targets & $31.25 \%$ \\
\hline
\end{tabular}

\section{Conclusion}

Although business organizations are taken as a source of creating employment stimulating economic growth, they are much more playing an inspiring role in implementing sustainability. At the same time, SDGs are also working as a lens for the business organization through which they can match the needs of society with the business goals and strategy. From this research, we can say that the Bangladeshi companies are still in the initial stage in case of disclosing SDGs in their reporting. This is because there are no mandatory guidelines for disclosing this information for them. They are only concerned about the work environment (SDG 8), new product development (SDG 9), human rights, engagement of females in business organizations (SDG 5), community development, etc. Very few, mostly pharmaceuticals companies, are aware of environmental issues (SDG 13). Although the disclosing practice is at the infant level, most of the organizations (around $80 \%$ ) have incorporated sustainable issues into day-to-day business activities. Banking organizations seem more aware than others as they are following Global Reporting Initiates guidelines to evaluate sustainability practices. As there is no specific framework for reporting SDGs by business organizations, companies are unsure about how to report, where to start and what is the standard SDG reporting. We have found that sample companies are reporting this information in a scattered way throughout the annual report. Simply, it can be said that most companies are concerned about SDGs, they involve SDGs into their management, but they are not reporting at a satisfactory level. Although this research contributes to SDG-related knowledge, it also suffers from some limitations. Firstly, the samples size is limited, and it is within the listed companies of DSE. The data were restricted to the presented data on annual reports. Thus, further research can be carried out involving more companies, other organizational factors related to reporting practice, and findings from this research can be used in further research based on primary data.

\section{REFERENCES}

Adams, C. (2020). The Sustainable Development Goals, Integrated Thinking, and the Integrated Report. Available online: http://integratedreporting.org/resource/ (accessed on 19 July 2020)
Agarwal, N., Gneiting, U. \& Mhlanga, R. (2017). Raising the Bar: Rethinking the Role of Business in the Sustainable Development Goals. Oxfam: Oxford, UK.

Basiago, A. D. (1999). Economic, social, and environmental sustainability in development theory and urban planning practice. The environmentalist, Boston: Kluwer Academic Publishers.

Breuer, A., Janetschek, H., \& Malerba, D. (2019). Translating sustainable development goal (SDG) Interdependencies into policy advice: Sustainability. Bonn, Germany: MDPI

Brundtland, G. H. (1987). World commission on environment and development (1987): Our common future. World Commission for Environment and Development. Oxford: Oxford University Press.

CGMA. (2018). Creating a sustainable future-The role of the accountant in implementing the sustainable development goals. https://www.cgma.org/content/dam/cgma/resour ces/reports/downloadabledocuments/cgmasustainable-dvelopment-goals-guide-apr-18.pdf (accessed on 17 July 2020).

Christofi, A., Christofi, P., \& Sisaye, S. (2012). Corporate sustainability: historical development and reporting practices. Management Research Review, 35(2), 157-172.

CPA. (2020). The 2030 agenda for sustainable development. https://www.cpacanada.ca/en/ (accessed on 17 July 2020)

IFAC. (2020). Sustainable Development Goals Disclosure (SDGD) Recommendations.

https://www.ifac.org/knowledge-

gateway/contributing-global-

economy/publications/sustainable-developmentgoals-disclosure-sdgd-recommendations (accessed on 15 July 2020)

Kroll, C., Warchold, A. \& Pradhan, P. (2019). Sustainable Development Goals (SDGs): Are we successful in turning trade-offs into synergies"? Palgrave Communications, 5, Article number: 140.

Makarenko, I. \& Plastun, A. (2017). The role of accounting in sustainable development. Accounting and Financial Control, 1(2), 4-12. http://dx.doi.org/10.21511/afc.01(2).2017.01

Mensah, J. (2019). Sustainable development: Meaning, history, principles, pillars, and implications for human action: A literature review. Cogent Social Sciences, $\quad 5(1)$, 1653531 https://doi.org/10.1080/23311886.2019.1653531

Neves, P. M. D. (2018). Literature Review on Sustainable Development: The spirit and critics of SD and SDGs. https://www.researchgate.net/publication/330182482

Pedersen, C. S. (2018). The UN Sustainable Development Goals (SDGs) are a great gift to business!. Procedia CIRP , 69, 21 - 24. 
PWC. (2015). Make It Your Business: Engaging with the Sustainable Development Goals Available online. https://www.pwc.com/gx/en/sustainability/SDG/ SDG\%20Research_FINAL.pdf (accessed on 14 July 2020).

Rahman, M. (Ed.) (2020). Four years of SDGs in Bangladesh: Non-state actors as delivery partners. Dhaka. Citizens Platform for SDGs, Bangladesh.

Reyes, G. E. (2001). Four main theories of development: modernization, dependency, word-system, and globalization. Nómadas. Revista Crítica de Ciencias Sociales y Jurídicas, 4(2), 109-124.

Singh, S. K. (2016). Sustainable Development: A Literature Review. The International Journal of Indian Psychology, 3(3).

Topple, C., Donovan, J. D., Masli, E. K., Borgert, T. (2017). Corporate sustainability assessments: MNE engagement with sustainable development and the SDGs Translate. Corp., 24, 61-71.

$--0--$ 